Meta

Journal des traducteurs

Translators' Journal

\title{
Some Considerations in the Translation of African Drama
}

\section{Joseph Che Suh}

Volume 47, numéro 3, septembre 2002

URI : https://id.erudit.org/iderudit/008021ar

DOI : https://doi.org/10.7202/008021ar

Aller au sommaire du numéro

Éditeur(s)

Les Presses de l'Université de Montréal

ISSN

0026-0452 (imprimé)

1492-1421 (numérique)

Découvrir la revue

Citer cet article

Che Suh, J. (2002). Some Considerations in the Translation of African Drama. Meta, 47(3), 370-374. https://doi.org/10.7202/008021ar

\section{Résumé de l'article}

Le présent article s'intéresse aux différentes formes que prend le théâtre africain au sud du Sahara. Il illustre et met en relief le fait que chacune de ces formes de théâtre présente des caractéristiques qui lui sont propres et que le traducteur se doit d'identifier et de faire ressortir dans le texte cible.
Ce document est protégé par la loi sur le droit d'auteur. L’utilisation des services d’Érudit (y compris la reproduction) est assujettie à sa politique d'utilisation que vous pouvez consulter en ligne.

https://apropos.erudit.org/fr/usagers/politique-dutilisation/ 


\title{
Some Considerations in the Translation of African Drama
}

\author{
JOSEPH CHE SUH \\ University of Buea, Buea, Cameroon
}

\begin{abstract}
RÉSUMÉ
Le présent article s'intéresse aux différentes formes que prend le théâtre africain au sud du Sahara. II illustre et met en relief le fait que chacune de ces formes de théâtre présente des caractéristiques qui lui sont propres et que le traducteur se doit d'identifier et de faire ressortir dans le texte cible.
\end{abstract}

\section{ABSTRACT}

This paper examines the types of African drama South of the Sahara. It illustrates and underscores the fact that each of the numerous sub-categories found in that part of the continent has its own distinctive characteristics which the translator must actively identify and map onto the target text.

\section{MOTS-CLÉS/KEYWORDS}

African literature, drama/theatre translation, literary translation, South of the Sahara, translation problems

Europe has a literary tradition which dates back many centuries and European literature, as we know it today owes quite much to Greek and Roman classics. Modern European literature thus developed and evolved as a result of the translation and imitation of the masterpieces from antiquity. African literature, on the other hand, is still very young compared to European literature and although it has made considerable progress much still has to be done. The translation of works of fiction written by Africans would therefore equally enhance the development of African literature as well as promote its spread both abroad and within the African continent itself across different cultural and linguistic barriers, some of which were artificially erected by the colonial masters and which, today, continue to render the uniform growth of African literature difficult.

Thus, in addition to unilingual epistemological and critical studies of African literature carried out by literary scholars and researchers, it is necessary for translation theorists and practitioners to step up reflection and activities on the translation of African literary works. Unfortunately, research carried out so far on the translation of African literature has tended to remain too broad in perspective with the result that the focus on each of the literary genres has been rather sketchy. We believe that more significant contribution to the development of African literature could be made and deeper insights into that literature gained by carrying out specific, detailed and in-depth studies on the translation of each of the genres.

In this regard, it is worth noting that translation activity as well as theoretical reflection on the translation of African literature has so far focused mainly on the novel at the expense of the other literary genres. Having noted this imbalance in the 
course of their research, some researchers have recommended that translation practitioners and theorists increasingly orient their activities towards other literary genres such as drama and poetry. ${ }^{1}$

Also worthy of note is the fact that literature of the African continent is often viewed from a rather general perspective: it is often broadly referred to as African literature. However, literature is usually not only culture-specific but it is also regionand country-specific. It is thus obvious that for a study to provide a detailed and comprehensive picture of the African reality it is necessary for all these specificities to be considered.

Consequently in order to ensure more successful translation of African literary works, it is necessary for translation practitioners and theorists to take into consideration not only the broad cultural characteristics of the African continent but also the regional and national specificities. This paper thus focuses not only on the broad problems of translating African drama from French into English but also and more specifically on the particular problems of translating drama from a specific African region: Africa South of the Sahara. ${ }^{2}$

African drama South of the Sahara comprises many types. Some of the main types include sacred dramas whose subjects and aims are religious. Sacred dramas are in turn sub-divided into ancestral or myth plays, masquerades or plays by age groups and cults, rituals, etc. In ancestral or myth plays the story derives directly from an ancestor - mythical founder well-known to the audience - , and the development is not so much by logic and discussion as by a poetic evocation of some religious experience shared alike by performer and spectators. The myths upon which many of the dramas are based serve to record the origins and raison d'être of the institutions and peoples who own them. Masquerade dramas for their part represent spirits and gods which their worshippers seek to propitiate. Furthermore, masquerade drama fosters good relations between members of one village and another. A people famous for their performance will always have spectators pouring in from everywhere to see their shows. In other words, the masquerade can become a village's or town's best advertisement.

Secular dramas, on the other hand, are distinct from sacred dramas and include sub-types such as civic dramas, dance or song dramas, etc. Civic dramas serve a civic and social purpose (as do tales and fables) by educating and initiating the young into the ways and duties of the community. In the process they help to knit together persons of similar background, giving them a common identity. Dance or song dramas for their part are straight entertainment with a lot of art and little or no ritual and religion. More often than not, the songs are straight satirical pieces although a good number are parables passing oblique social comments and criticisms.

Apart from sacred and secular dramas there are also mixed dramas in which the elements of pleasure and entertainment cannot be neatly pared from the devotion and ecstasy of religious worship. Also included in the category of mixed dramas is what literary critics have referred to as "literary drama" which, according to them, has "its heart right here in Africa and its head deep in the wings of European and American theatre." ${ }^{3}$ It is thus evident from the above brief survey that African drama South of the Sahara is complex and varied.

It is equally evident that each of these types of drama has its own distinctive characteristics which clearly differentiate it from the other types and which the 
translator must take into consideration if the drama type is to be identified as such in the target language/culture.

In order to effect the translation of an African play South of the Sahara, therefore, it would be necessary for the translator to first of all identify the drama type to which the play belongs. Next, it would be necessary for the translator to identify and take into consideration the distinctive characteristics of the drama type in question (i.e. its objective, primary audience, structure, style, theatrical conventions, accessories, etc.). Within the scope of this paper let us consider for example the case of sacred dramas and more specifically that of ritual drama alone which constitutes one of the sub-categories of that drama type. It would be necessary for the translator to take into consideration and map onto the target text/target language the following characteristics typical of ritual drama:

1. The ritual is first of all preparation to attain a certain state. An initial period zero is created which could be likened to the "beginning." An important problem is posed and the whole community is expected to resolve it.

2. The ritual is like a spiral process which leads one from one point of conscience to another higher point of conscience.

3. All the participants (actors), in a creative manner, contribute in resolving the drama (i.e. problem posed).

4. The scene and the poetic atmosphere are intimately linked. Both evoke the human and the supernatural worlds.

5. The ritual is characterised by its stereotypical nature. Its effectiveness is based on repetition e.g. a gesture or a word is repeated so that the participants should gasp it fully and digest it in their objective consciences. It is in this respect that one finds many refrains aimed at focusing the attention of the spectators on the importance of the ritual or to annul its disquietening/disturbing effects.

6. The ritual is a symbolic action and each of its phases has a symbolic value. Every gesture, accessory, décor, or word/speech constitutes an active discourse and it engages the participation of all the participants.

7. With respect to the costumes, their colour affects the psyche/mind and indicates to each actor/participant what conduct to imprint or give his role.

8. Gesture is codified: it heals, purifies, accuses, designates, builds and destroys. Each time its edification or the intention behind it takes the place of speech and transforms the established order.

9. Accessories are not used for mere décor but for the essential role they have to play. They equally carry a message.

10. Music is there not only for the aesthetics but also to play a communication role. The drum/tam-tam has its own coded language and dialogues with the initiated.

11. In certain instances, speech becomes sacred and is manipulated with care by specialists (porteurs de la parole) who are technicians who transmit the message through speech in accordance with the rules of the art.

12. Incantation is the preferred/favourite form of text/speech. It follows a rigorous pattern underlined by a number (in general, an even number for women and an uneven one for men) and must be said/spoken following a rhythm and a musical note. The sounds are of vital importance (they cure, appease or stimulate/excite certain sensitive points/parts).

In addition to the above considerations, the translator must constantly bear in mind that most African playwrights still use European languages to present or describe the cultural and socio-political experiences of their different countries and villages in which their inspiration and creativity are rooted. Their writings in these European 
languages could be said to constitute a form of translation from their mother tongues for which there is no corresponding written original but rather only an oral one. The playwrights' texts therefore often carry a double language: the European language and the playwright's mother tongue. The African playwrights' special use of language resulting from and reflecting this ambivalent situation is often evident in their plays at various levels (lexical, syntactic, imagery, proverbs, dialogue, rhetorical and other stylistic devices). All this of course has an incidence on the translation of the plays as the playwright's indigenous thought patterns and linguistic features in the source text would require that the translator analyses and interprets them appropriately in order to transfer them adequately to the target text.

\section{NOTES}

1. Moses Nunyi Nintai (1993) in his Ph.D. thesis entitled "Mapping Transference: Problems of African Literature and Translation from French into English" submitted to the Graduate School of the University of Warwick suggests further research on the translation of oral literature, drama and poetry to complement his work which focuses mainly on the African novel.

2. The drama of this region falls under Black African literature as opposed to Arab literature of the Maghreb (North Africa).

3. Cf. J.P. Clark (1981): "Aspects of Nigerian Drama” in Drama and theatre in Nigeria, Lagos, Nigeria Magazine p. 66. The works of Wole Soyinka and J.P. Clark are classed under literary drama.

\section{REFERENCES}

Aaltonen, S. (1993): "Rewriting the Exotic: The Manipulation of Otherness in Translated Drama," in Proceedings of XIII FIT World Congress, ed. by Catriona Picken. London: Institute of Translation and Interpreting, 26-33.

AdE, O.S. (1986): "The Role of the Translator of African Written Literature in Inter-cultural Consciousness and Relationship," in Meta, Vol. 31 No. 3, pp. 291-299.

Amvarez, R.M. (1993): "A view from the stage: Arthur Miller in Spanish," in Proceedings of XIII FIT World Congress. London: Institute of Translation and Interpreting, 17-25.

Asanga, S. (1985): African Theatre Review. Yaounde: SOPECAM.

Banham, M. (1976): African Theatre Today. London: Pitman Publishing.

BASSNETT-McGuire, S. (1991): Translation Studies. London: Routledge.

— (1991): "Translating for the Theatre: The Case Against Performability" TTR, Vol. IV No. 1.

BRISSET, A. (1988): "Le publique et son traducteur: profil idéologique de la traduction théâtrale au Québec" TTR, Vol. 1 No. 1, 127-138.

Butake, B. and G. Dоно (1988): Théâtre camerounais. Yaounde: Centre camerounais de l'IIT.

Chinweizu et al., eds (1983): Toward the Decolonization of African Literature. Washington: Howard University Press.

Clark, J.P. (1981): “Aspects of Nigerian Drama," in Drama and Theatre in Nigeria. Nigeria Magazine.

Etherton, M. (ed) (1982): African Plays for Playing 2. London: Heinemann.

FerenciK, J. (1970): “De la spécification de la traduction de l'œuvre dramatique," in The Nature of Translation: Essays on the Theory and practice of Literary Translation, ed. by James S. Holmes. Paris: Mouton, pp. 144-150.

GadDis, M.R. (1997): Translation and Literary Criticism: Translation and Analysis. Manchester: St. Jerome.

Hamberg, L. (1969): "Some practical considerations concerning dramatic translation" Babel, Vol. XV No. 2, pp. 90-95

Koustas Jone (1988): “Traduire ou ne pas traduire le théâtre” TTR Vol. 1 No. 1, 127-138.

KraUSE, M.T. (1993): "More than mere words: literary translation as literary interpretation," in Proceeding of XIII FIT World Congress. London: Institute of Translation and Interpreting, 1-9. 
Leloup, J. (1989): “Le théâtre universitaire," in Littérature camerounaise. Yaounde: Notre Librairie. Mateso, L. (1986): La Littérature africaine et sa critique. Paris: ACCT/Kartala.

Moravkova, A. (1993): "Les problèmes spécifiques de la traduction des drames," in Proceeding of XIII FIT World Congress, ed. by Catriona Picken. London: Institute of Translation and Interpretation, 34-34.

NintaI, M.N. (1993): "Mapping Transference: Problems of African Literature and Translation from French into English." Unpublished doctoral thesis, University of Warwick.

Rotimi, O. (1981): "The Drama in African Ritual Display," in Drama and Theatre in Nigeria. Lagos: Nigeria Magazine.

Wellwarth, G.E. (1977): "Special Considerations in Drama Translation," in Translation in the Humanities, ed. by Marilyn Gaddis Rose. State University of New York at Binghamton, 5359.

Yemi, O. (1981): "Nigerian Theatre and Drama: A Critical Profile," in Drama and Theatre in Nigeria. Lagos: Nigeria Magazine. 